\title{
Dialychone and Paradialychone (Polychaeta: Sabellidae) from the Mediterranean Coast of Egypt with description of Dialychone egyptica sp.n.
}

\author{
S.A. Selim¹, A.V. Rzhavsky², T.A. Britayev² \\ ${ }^{I}$ National Institute of Oceanography and Fisheries, El-Anfoushy, Kayet-Beh, Alexandria, Egypt. \\ e-mail:selim_samia@yahoo.com \\ ${ }^{2}$ A.N. Severtsov Institute of Ecology and Evolution, RAS, Leninskij Prospekt 33, Moscow, Russia, \\ 119071. \\ e-mail:rzhavskij@mail.ru,britayev@yandex.ru
}

ABSTRACT: A new species of Dialychone, D. egyptica sp.n. (Sabellidae) is described from the Mediterranean Coast of Egypt. The material was collected from soft bottom at 60 $\mathrm{m}$ depth. It is unique among the genus in having an abdominal glandular ridge on chaetiger 13. The new species is also characterized by having pygidial cirrus, medium sized radiolar tips and long radiolar pinnules, anterior peristomial ring lobe incised and exposed beyond collar, a trapezoidal ventral collar shield, and paleate chaetae with long mucro. The distributions of Dialychone collaris (Langerhans, 1880), D. usticensis (Giangrande et al., 2006), D. dunerificta (Tovar-Hernández et al., 2007), and Paradialychone gambiae (Tovar-Hernández et al., 2007) along the Mediterranean coast of Egypt are also presented. P. gambiae reported for the first time in the Egyptian coasts, while D. dunerificta was previously recorded as Chone duneri Malmgren, 1867.

How to cite this article: Selim S.A., Rzhavsky A.V., Britayev T.A. 2012. Dialychone and Paradialychone (Polychaeta: Sabellidae) from the Mediterranean Coast of Egypt with description of Dialychone egyptica sp.n. // Invert. Zool. Vol.9. No.2. P.105-114.

KEY WORDS: Polychaeta, Sabellidae, Dialychone, Paradialychone, Dialychone egyptica sp.n., Chone, Mediterranean Sea, Egypt.

\section{Dialychone и Paradialychone (Polychaeta: Sabellidae) средиземноморского побережья Египта с описанием нового вида Dialychone egyptica sp.n.}

\author{
С.А. Селим ${ }^{1}$, А.В. Ржавский르, Т.А. Бритаев²
}

${ }^{1}$ Национальный институт океанографии и рыбного хозяйства, Александрия, Египет. e-mail:selim_samia@yahoo.com

${ }^{2}$ Институт проблем экологии и эволюции им. А.Н. Севериова РАН, Ленинский пр. 33, Москва, 119071.

e-mail:rzhavskij@mail.ru,britayev@yandex.ru

PЕЗЮМЕ: Описан новый вид Dialychone egyptica sp.n. (Sabellidae) со средиземноморского побережья Египта. Материал собран с мягкого грунта на глубине 60 м. Ото 
всех остальных видов рода Dialychone новый вид отличается наличием абдоминального железистого пояска на 13-м щетинковом сегменте. В комплекс других характерных признаков D. egyptica входят: наличие пигидиального усика, жаберные лучи со среднего размера кончиками и длинными пиннулами, передняя перистомальная лопасть с вырезом, открытая за пределами воротничка, трапециевидные вентральные железистые поля воротничка и шпателевидные щетинки с длинным кончиком. Также приводятся данные о распространении у средиземноморского побережья Египта Dialychone collaris (Langerhans, 1880), D. usticensis (Giangrande et al., 2006) и D. dunerificta (Tovar-Hernández et al., 2007), а также Paradialychone gambiae (TovarHernández et al., 2007). P. gambiae отмечен здесь впервые, тогда как D. dunerificta ранее ошибочно определяли как Chone duneri Malmgren, 1867.

Как цитировать эту статью: Selim S.A., Rzhavsky A.V., Britayev T.A. 2012. Dialychone and Paradialychone (Polychaeta: Sabellidae) from the Mediterranean Coast of Egypt with description of Dialychone egyptica sp.n. // Invert. Zool. Vol.9. No.2. P.105-114.

\section{КЛЮЧЕВЫЕ СЛОВА: Polychaeta, Sabellidae, Dialychone, Paradialychone, Dialychone} egyptica sp.n., Chone, Mediterranean Sea, Egypt.

\section{Introduction}

The Sabellidae Latreille, 1825 inhabit all seas, both in hard and soft substrates, from intertidal to abyssal depths, including coral reefs, but are also found in fresh waters (Fitzhugh, 1989; Rouse, Pleijel, 2001). The family comprised about 490 species, with more than 70 belonging to the Fabriciinae, and over 400 to Sabellinae (Rouse, Pleijel, 2001; Tovar-Hernández, Dean, 2010). All sabellids (including Chone Krøyer, 1856 and the closely related genera Amphicorina Claparede, 1864, Euchone Malmgren, 1866, and Jasmineira Langerhans, 1880 ) are suspension feeders, while some small forms may also be deposit feeders.

The formally described 59 species of Chone show a marked variability in diagnostic features (Tovar-Hernández, 2007a), which could result in splitting of the genus (Fitzhugh, 1989; TovarHernández, Sosa-Rodríguez, 2006). The so called Chonea group, sensu Cochrane (2003) (i.e. Chone and its related genera) represent one of the least understood groups within the Sabellinae (Fitzhugh, 1989; Cochrane, 2003). In fact, Chone as a group is not defined by any synapomorphy, and the whole complex could possibly be divides into a series of monophyletic genera, based on the presence or absence of dorsal radiolar appendages and abdominal uncinal variation (Fitzhugh 1989). The taxonomy of Chone is, thus, confused, with several evident gaps still unsolved (Giangrande et al., 2006; Tovar-Hernández et al., 2007).

This problem was particularly evident in the Mediterranean Sea (Tovar-Hernández et al., 2007) as a result of the insufficient and incomplete original descriptions of the existing species, despite the extensive studies addressing the genus in this area (Giangrande, 1992; Giangrande, Licciano, 2006; Giangrande et al., 2006). After the first studies carried out by Banse (1972), the study of the Chonea complex and, more specifically, of the genus Chone has been the subject of a worldwide revision (TovarHernández, 2005, 2007a,b; Tovar-Hernández, Sosa-Rodríguez, 2006; Tovar-Hernández et al., 2007), which lately had been solved in a recent cladistic analysis (Tovar-Hernández, 2008). As a result, three monophyletic genera - Chone, Dialychone Claparède, 1870 and Paradialychone Tovar-Hernández, 2008, include now the species previously assigned to Chone.

The current knowledge on the polychaete fauna from Egyptian waters is very poor, and the genus Chone, Dialychone, and Paradialychone are not an exception. Only four species of the first two genera have been recorded to date, all 


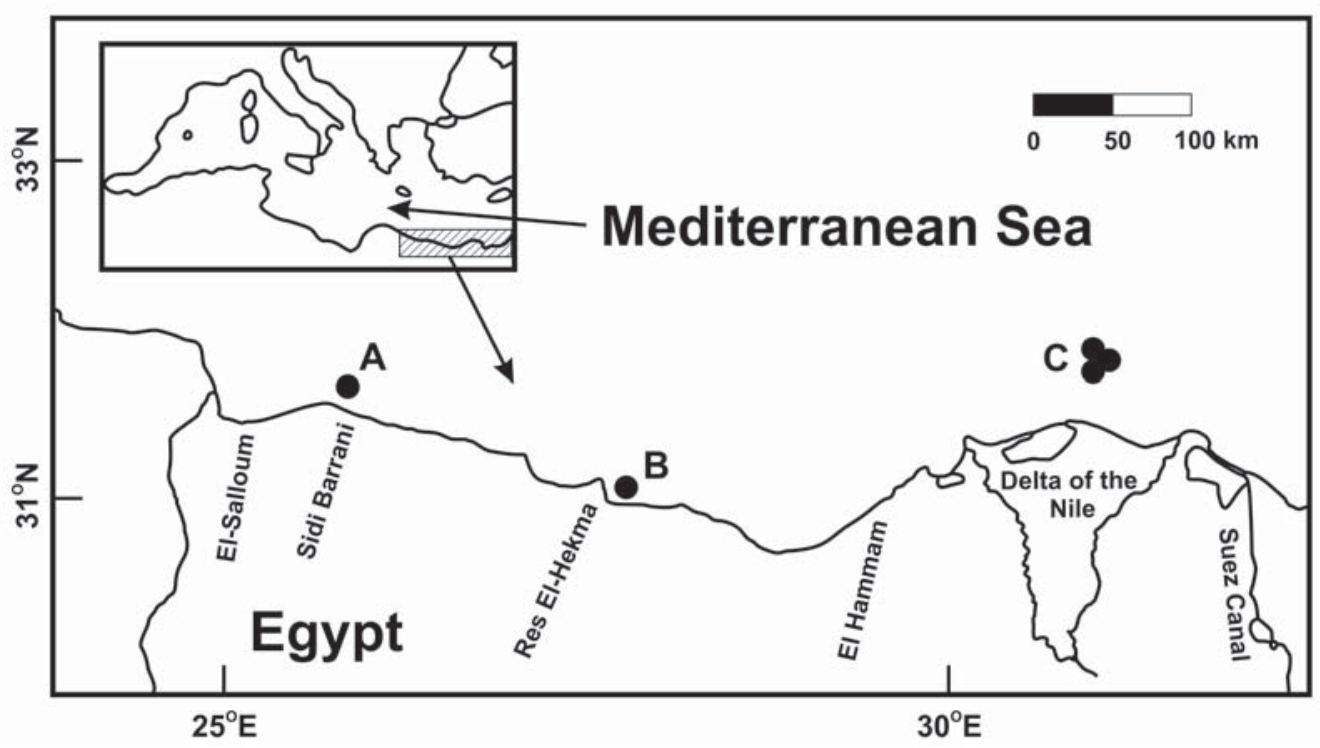

Fig.1. Map of the studied area. A - Sidi Barrani; B — Res-El-Hekma; C - Delta of the Nile. Рис.1. Район исследований, кружками обозначены места взятия проб.

of them as belonging to Chone: C. collaris Langerhans, 1880, C. duneri Malmgren, 1867, C. usticensis Giangrande et al., 2006, and C. infundibuliformis Krøyer, 1856. The later, found in the Timsah Lake (Suez Channel) by the Cambridge Expedition in 1924 (Potts, 1928), is the single one still included in Chone and, thus, it is not treated here.

The present study summarized the current knowledge on the species of Dialychone and Paradialychone from the Egyptian Mediterranean waters and describes Dialychone egyptica sp.n., found in the same region.

\section{Material and methods}

The materials were obtained during irregular surveys of the western Egyptian Mediterranean Coast carried out by the National Institute of Oceanography and Fisheries of Alexandria, Egypt, from February 2006 to March 2010. The studied area was located between El-Hammam and El-Salloum (Fig. 1). All samples were first anaesthetized with $7.5 \%$ magnesium chloride and then fixed in 5\% seawater formalin. In the laboratory, they were washed through $0.5 \mathrm{~mm}$ mesh sieve. The retained material was sorted and preserved in $70 \%$ ethanol. The fauna, polychaetes included, was sorted under a dissecting microscope, and identified to species level.

Microphotographs of the new species were obtained with a digital camera Leica DFC 295 attached to a compound microscope Leica MZ6, and line drawings were made with help of camera lucida Olympus U-DA attached to a compound microscope Olympus BX 41. The type material has been deposited in the collection of Zoological Institute of the Russian Academy of Science, St. Petersburg, Russia (ZISP).

\section{Results}

\section{Dialychone egyptica sp.n.}

Material. Holotype (ZISP, Reg. No 1/50580), female, Mediterranean Sea, $31^{\circ} 44.12^{\prime} \mathrm{N}, 25^{\circ} 59.5^{\prime} \mathrm{E}$, (Sidi-Barrani, Egypt), about $60 \mathrm{~m}$ depth (site A, Fig. 1), sandy bottom, February, 2006; R/V Salsabeel.

Description. Tube unknown. Body complete, cream-colored, $3.2 \mathrm{~mm}$ long, $0.37 \mathrm{~mm}$ wide. Trunk cylindrical, abdomen dorso-ventrally depressed posteriorly (Fig. 2A), with simple prepygidial depression; chaetigers biannulate. 
Branchial crown: $1.2 \mathrm{~mm}$ long, with five pairs of radioles, two shorter than others (Fig. 2A-C). Insertion of lobes not exposed beyond collar. Radiolar skeleton axis with two cell rows. Pinnules long, equal in length, with radiolar tips medium sized (Fig. 2F). Lateral flanges very narrow. Palmate membrane about one sixth of the length of the branchial crown. Dorsal lips triangular, about two times longer than wide, much shorter than dorsal pinnular appendages. One pair of dorsal pinnular appendages, about one third of the length of the branchial crown. Dorsal radiolar appendages not seen. Ventral lips very short, located at base of dorsal lips. One pair of ventral radiolar appendages about one-half of the length of the branchial crown.

Peristomium: Anterior peristomial ring lobe distally incised, exposed beyond collar. Posterior peristomial ring collar with entire anterodorsal, ventral, and lateral margins. Entire length of mid-dorsal collar margins forming a narrow gap (Fig. 2 C-E). Dorsal and ventral collar margins equal in length (Fig. 2E). Dorsal pockets well developed. Ventral shield of collar difficulty discernible, trapezoidal in shape.

Thorax: Eight biannulate thoracic chaetigers. Glandular ridge dorsally and ventrally encircling chaetiger 2, uniformly narrow, (Fig. 2B, C). Ventral thoracic shields absent. First notopodial fascicle with two groups of elongate narrowly hooded chaetae. Notopodial fascicle of chaetigers 2-8 consisting of: superior group with elongate, narrowly hooded chaetae (Fig. $3 \mathrm{~A}$ ), inferior group with one anterior row of bayonet chaetae (Fig. 3C), and two posterior rows of paleate chaetae with long mucro (Fig. 3D). All thoracic neuropodia with one row of 10-14 handled acicular uncini per torus, narrowly hooded, main fang surmounted by 5 rows of teeth decreasing in size from main fang away, dentation occupying about one half of main fang length (Fig. 3E).

Abdomen: Twenty abdominal chaetigers, narrow glandular ridge encircling chaetiger 13 similar to that of chaetiger 2 (Fig. 2A). Anterior neuropodial abdominal chaetigers with two transverse rows of elongate, narrowly hooded chaetae (Fig. 3B), those of upper row about twice shorter than those of lower one. Notopodia with 8-10 uncini per torus; main fang surmounted by $5-6$ rows of equal size teeth occupying about one half of main fang length; main fang not extending beyond breast, handles absent. Posterior abdominal segments with very elongate narrowly hooded chaetae and one row of modified uncini. Uncini surmounted by 6-7 regular rows of teeth equal in size. Main fang nearly equal in length and similar to the neighboring teeth, not extending beyond breast. Breast rectangular, wider than that of anterior abdominal uncini (Fig. 3F, H).

Pygidium: Pygidium semi-spherical, with long pygidial cirrus (Fig. 2D).

Gametes: Female with oocytes of irregular shape, with large nucleus and small intensively stained nucleolus, with $45 \mu \mathrm{m}$ of maximum diameter (Fig. 3G).

Methyl green staining pattern: Distal margin of collar faintly stained; remaining sections intensively and uniformly stained, with dense small dark spots on both dorsal and ventral sides, more dense on dorsal side. Ventral shield difficulty discernible, dark, fully stained. First two thoracic chaetigers intensively stained, darker than following ones, with staining gradually decreasing posteriorly. Remaining thoracic and abdominal chaetigers with completely glandular epidermis, staining uniformly dorsally and ventrally, except on intersegmental furrows. Posterior abdomen unstained. Pygidium darkly stained. Glandular ridges on second and thirteen chaetigers surrounded by two intensely stained bands.

Differential diagnosis and remarks. The genus Dialychone Claparède, 1780 was re-established by Tovar-Hernández (2008) and includes 17 species besides the new species here described (Tovar-Hernández, 2008; Nishi et al, 2009; Tovar-Hernández, Dean, 2010). Dialychone egyptica sp. nov. agrees with the main diagnostic features of the genus: gradual decrease in dentition of thoracic uncini away from the main fang, modified posterior uncini (with the main fang nearly equal in length to the neighboring teeth, with wide breast), and a simple pre-pygidial depression. 

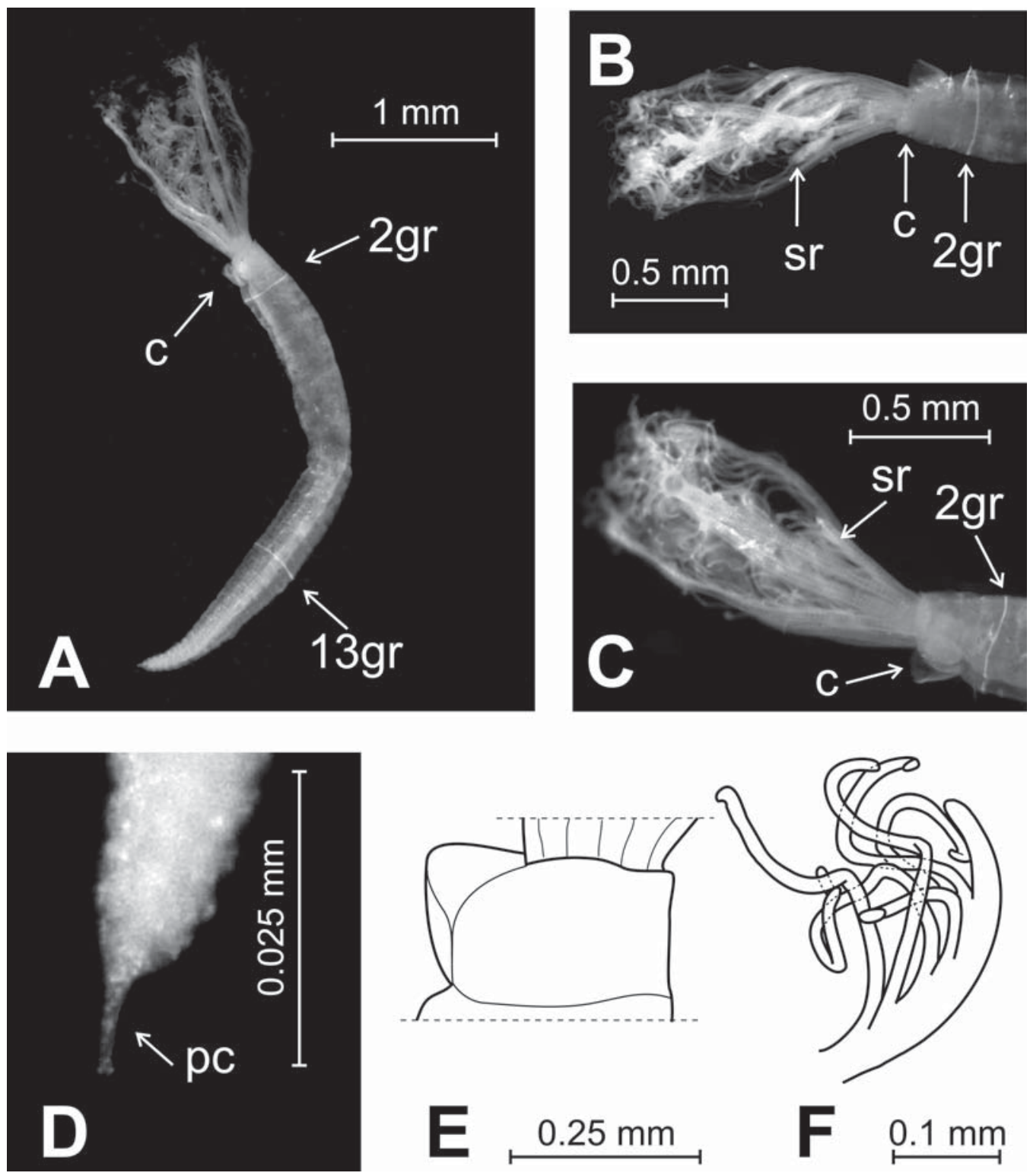

Fig. 2. Dialychone egyptica sp.n.:

A - whole worm, lateral view; B - anterior end, ventro-lateral view; C - anterior end, dorso-lateral view; D posterior end, dorsal view; E — anterior end, dorso-lateral view; F — radiolar tip. Abbreviations: c - collar; $2 \mathrm{gr}$ second glandular ridge; $13 \mathrm{gr}$ - thirteen glandular ridge; $\mathrm{pc}$ - pygidial cirrus; $\mathrm{sr}$ - short radiole. Scale bars: A — 1 $\mathrm{mm}, \mathrm{B}-\mathrm{C}-0.5 \mathrm{~mm}, \mathrm{D}-\mathrm{E}-0.25 \mathrm{~mm}, \mathrm{~F}-0.1 \mathrm{~mm}$.

Рис. 2. Dialychone egyptica sp.n.:

А - целый червь, вид сбоку; В - передняя часть тела, вентро-латеральный вид; С - передняя часть тела, дорзолатеральный вид; D - задняя часть тела, вид сверху; Е - передняя часть тела, дорзолатеральный вид; F кончик жаберного луча. Условные обозначения: с - воротничок; $2 \mathrm{gr}$ - железистый поясок 2-го сегмента; $13 \mathrm{gr}$ - железистый поясок 13-го сегмента; pc — пигидиальный усик; sr — укороченный жаберный луч. Масштаб: A - 1 мм, B-C - 0,5 мм, D-E - 0,25 мм, F-0,1 мм. 
The presence of a glandular ridge on chaetiger 2 is one of the main diagnostic characters for "Chonea" group (Cochrane, 2003), which agrees with its definition as primitive character (Banse, 1972; Fitzhugh, 1989), However, some species of Dialychone possess this glandular ridge alone, while others have one or more ridges either on thoracic or abdominal chaetigers or in both (Banse, 1972; Tovar-Hernández, 2007b). Glandular ridges on anterior abdominal chaetigers occurs in Dialychone veleronis (Banse, 1972) and Dialychone albocincta (Banse, 1972), the latter having two glandular ridges on each thoracic chaetigers in addition to those in the anterior abdominal ones (Banse, 1972; Tovar-Hernández, 2007b). D. egyptica sp.n. differs from the above mentioned species in being the single species possessing one abdominal glandular ridge on chaetiger 13 .

Until recently, all specimens having caudal cirrus have been reported as Chone filicaudata Southern, 1914, now included in Paradialychone (Tovar-Hernández, 2008). However, $P$. filicaudata (Southern, 1914) seems to be restricted to the North Sea (Tovar- Hernández et al., 2007), and several species of Dialychone and Paradialychone (including several Mediterranean taxa) bear pygidial cirrus (TovarHernández, 2005; Giangrande et al., 2006; Tovar-Hernández et al., 2007; Tovar-Hernández, 2008; Tovar-Hernández, Dean, 2010): Dialychone arabica Tovar-Hernández, Dean, 2010; D. usticensis, Paradialychone americana (Day, 1973), P. filicaudata, and P. gambiae (TovarHernández et al., 2007). D. egyptica sp.n. also belongs to the group of species having pygidial cirrus. The presence of pygidial cirrus in $D$. arabica is not constant, but most of the specimens have triangular posterior margin. D. egyptica sp.n. and $D$. usticensis also differ from $D$. arabica in having collars with unnotched ventral margin (notched in D. arabica). D. egyptica sp.n.. has incised anterior peristomial ring lobe (triangular in D. arabica and D. usticensis), radiolar tips medium-sized with long pinnules (very long in D. usticensis, with pinnules equal in size along the entire radioles; short in $D$. arabica, with distal pinnules longer than prox- imal); palmate membrane about $1 / 6$ the length of the branchial crown (about $1 / 2$ in D. arabica and D. usticensis); and a collar with a trapezoidal ventral shield (horseshoe-shaped in D. arabica and D. usticensis).

Etymology. The species name means "from Egypt", the country in which coasts the species has been found.

Ecology. The single known specimen was found at about $60 \mathrm{~m}$ depth, on sandy bottoms (water temperature: $17.9^{\circ} \mathrm{C}$; salinity: $38.98 \%$; PH: 8.2; dissolved $\mathrm{O}_{2}: 4.7 \mathrm{ml} / 1$ ).

Distribution. Mediterranean Sea, $31^{\circ} 44.12^{\prime}$ N, 2559.5’ E (Sidi-Barrani, Egypt).

\section{Dialychone collaris (Langerhans, 1880)}

Chone collaris Langerhans 1880: 116, fig. 29 a-f; Fauvel, 1927: 337, Fig. 116 p-x; Day, 1967: 777, Fig. 37.7. a-f; Giangrande, 1992: 524-525, Figs. 13 a-f, 14 ad; Tovar-Hernández et al., 2007: 324-326, Fig. 5 A-N; Selim, 2008: 111-113, Fig. 2 j-t.

Dialychone collaris: Tovar-Hernández, 2008: 2219.

Material. One specimen from the coastal waters of the Egyptian Mediterranean Sea: Ras El-Hekma, February 2006 (Fig. 1, Site B).

Diagnosis. Insertion of the branchial lobes not exposed beyond collar. Radioles with short tips, lateral flanges broad. Dorsal lips long, triangular, erect. Ventral lips short, rounded. Anterior peristomial ring lobe distally bilobed and exposed beyond collar. Dorsal pockets well developed. Ventral collar shield horseshoeshaped, swollen. Paleate chaetae with mediumsized mucro. Thoracic and anterior abdominal uncini with the main fang surmounted by four rows of equal-size teeth. Posterior abdominal uncini modified, with the main fang surmounted by seven rows of equally small teeth.

Taxonomic notes. Previous records from the Egyptian waters referred the species to Chone (Selim, 2008). This is, thus, the first report of the species as belonging to Dialychone from Egyptian waters. The species is unique among the genus in having a collar with crenulated anterior margin.

Ecology and distribution. The specimen was found at $63 \mathrm{~m}$ depth on silty sand bottoms. The species is known from the European coasts, from Mediterranean to Norwegian Sea, Madei- 

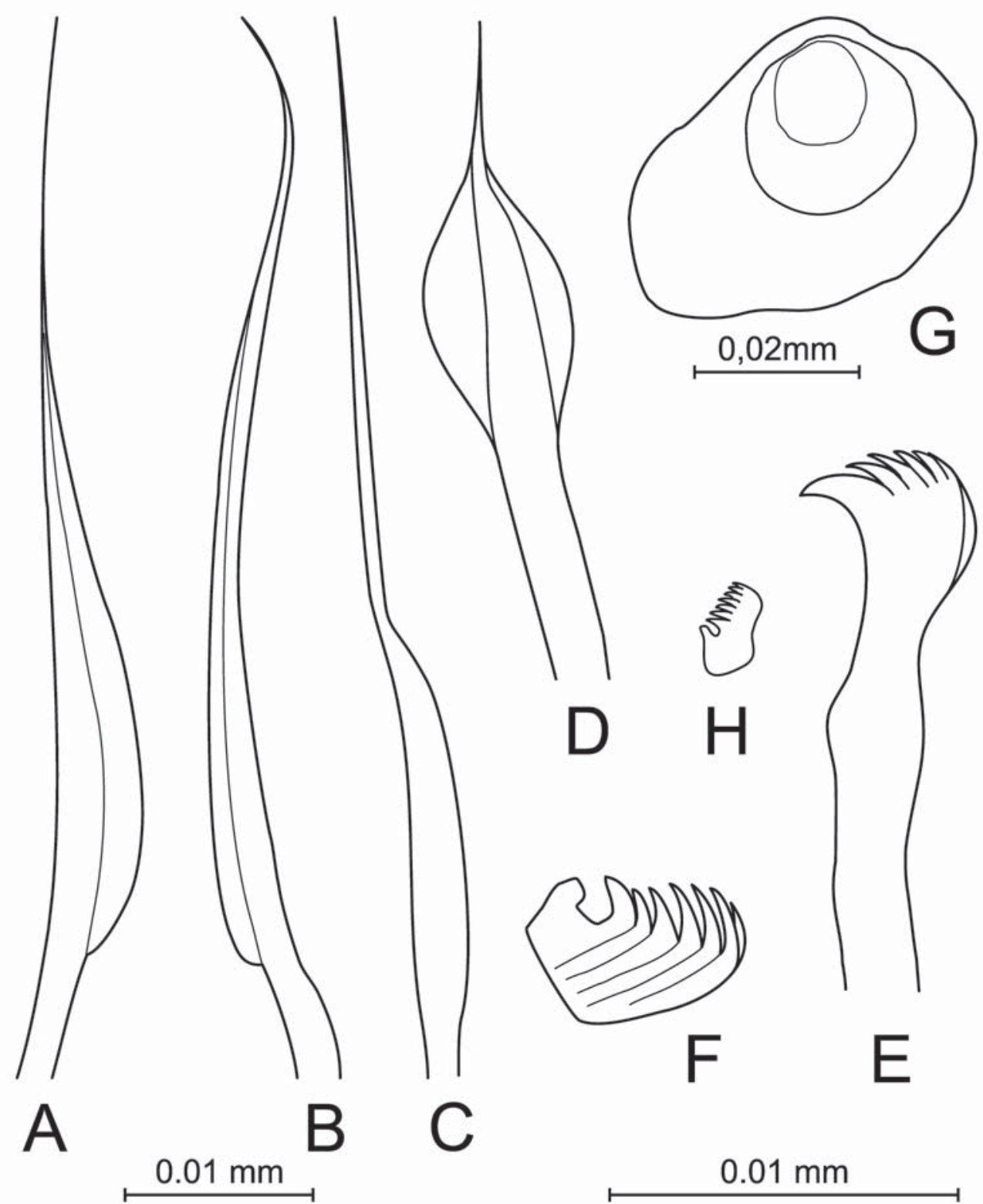

Fig. 3. Dialychone egyptica sp.n.:

A - thoracic notochaeta; B - anterior abdominal neurochaeta; C - bayonet chaeta; D - thoracic paleate chaeta; $\mathrm{E}$ - thoracic uncinus; $\mathrm{F}$ - anterior abdominal uncinus; $\mathrm{G}$ - oocyte; $\mathrm{H}$ - posterior abdominal uncinus. Scale bars: AD, E-F, H- $0.01 \mathrm{~mm}, \mathrm{G}-0.02 \mathrm{~mm}$.

Рис.3. Dialychone egyptica sp.n.:

A - торакальная нотохета; В - абдоминальная нотохета из передней части абдомена; $\mathrm{C}-$ штыковидная щетинка; D - торакальная шпателевидная щетинка; $\mathrm{E}$ - торакальная анцини; $\mathrm{F}$ - абдоминальная анцини из передней части абдомена; $\mathrm{G}$ - ооцит; $\mathrm{H}$ - абдоминальная анцини из задней части абдомена. Масштаб: A-D, E-F, $\mathrm{H}-0,01$ мм, $\mathrm{G}-0,02$ мм. 
ra and Canary Islands, Red Sea and, probably, the Persian Gulf. It is usually found in shallow waters (0.5-10 $\mathrm{m}$ depth), from rocky bottoms covered with photophilic algae, often among other polychaetes (e.g. Syllis prolifera Krohn, 1852, Platynereis dumerilli (Audouin et MilneEdwards, 1834) and mollusks (e.g. Bittium latreilii (Payraudeau, 1826), but it can be occasionally found in sandy bottoms and among seagrass meadows (Giangrande, 1992; TovarHernández et al., 2007; Fauchald, Bellan, 2012).

\section{Dialychone dunerificta (Tovar-Hernández et al., 2007)}

Chone duneri: Fauvel, 1937: 44; Giangrande, 1992: 525, Figs 15-16, Abd-Elnaby, 2005: 164, Fig. $107 \mathrm{a}-\mathrm{f}$ (non Malmgren, 1867).

Chone dunerificta Tovar-Hernández et al., 2007: 329331, Fig. 7 A-N.

Dialychone dunerificta: Tovar-Hernández, 2008: 2219.

Material. Three specimens from the coastal waters of the Egyptian Mediterranean Sea: Sidi-Barrani, September, 2006 (Fig. 1, Site A) and in front of the Egyptian Delta, May 2008 (Fig. 1, site C).

Diagnosis. Insertion of the branchial lobes exposed beyond collar. Radiolar tips long, lateral flanges narrow. Triangular erect dorsal lips, small rounded ventral lips. Anterior peristomial ring lobe distally bilobed and exposed beyond collar. Dorsal pockets not developed. Ventral collar shield horseshoe-shaped, not swollen. Paleate chaetae with medium-sized mucro. Thoracic and anterior abdominal uncini with the main fang surmounted by four rows of equalsized teeth. Posterior abdominal uncini modified, the main fang surmounted by 6-7 rows of equalsize teeth.

Taxonomic notes. Previous reports of $C$. duneri from the fishery grounds of Alexandria waters and Abu-Qir Bay (Fauvel, 1937, AbdElnaby, 2005) are here attributed to D. dunerificta, based on the recent description and its updated range of distribution (Tovar-Hernández et al., 2007). Although both species really are very similar, $D$. dunerificta is probably the most widely distributed within the Mediterranean Sea (often confused with C. duneri).

Ecology and distribution. Our material was found at 32-63 $\mathrm{m}$ depth on sandy and muddy bottoms. Earlier records (as $C$. duneri) off the Egyptian coast were at 32-126 m depth from muddy bottoms, and among fouling communities (Fauvel, 1937; Abd-Elnaby, 2005). It is known also from Tyrrhenian, Ligurian, and Adriatic Seas, and from Canary Islands at 5-34 $\mathrm{m}$ depth from sandy bottoms (Giangrand, 1992; Tovar-Hernández et al., 2007).

Dialychone usticensis (Giangrande et al., 2006)

Chone usticensis Giangrande, et al., 2006: 53-57, Figs 2-4; Tovar-Hernández et al., 2007: 335-336, Fig. 11 A-B; Selim, 2008: 113, Fig. 3 a-j.

Dialychone usticensis: Tovar-Hernández, 2008: 2219.

Material.: Seven specimens from coastal waters of the Egyptian Mediterranean Sea: of which two specimens from Ras El-Hekma, February 2006, (Fig. 1, Site B) and the remaining of the Egyptian Delta, February 2008 (Fig. 1, Site C).

Diagnosis. Insertion of the branchial lobes not exposed beyond collar. Radiolar tips extralong, radiolar flanges narrow. Dorsal lips pointed, erect, longer than wide. Ventral lips rounded. Anterior peristomial ring lobe triangular, not exposed beyond collar. Dorsal pockets not developed. Ventral collar shield horseshoeshaped, swollen. Paleate chaetae with long mucro. Thoracic, anterior neuropodial abdominal, and posterior abdominal uncini with the main fang surmounted by four, five, and six rows of equally-sized teeth, respectively. Pygidium triangular with long cirrus.

Taxonomic notes. Previously this record from the Egyptian waters was attributed to genus Dialychone (Selim, 2008).

Ecology and distribution. Our specimens were found at 59-63 m depth on silty sand and muddy bottoms. Also recorded from Tyrrhenian Sea (Ustica Is. and Gulf of Naples) and Canary Islands at 3-9 $\mathrm{m}$ depth, on soft-bottoms mainly composed of medium sand and biogenic and volcanic particles (Giangrande et al. 2006; Tovar-Hernández et al 2007).

Paradialychone gambiae (Tovar-Hernández et al., 2007)

Chone gambiae Tovar-Hernández et al., 2007: 332334, Fig.9 A-K. 

2221.

Paradialychone gambiae: Tovar-Hernández, 2008:

Material. One specimen without branchial crown, found in coastal waters of Egyptian Mediterranean Sea: Sidi-Barrani, March 2010 Fig. 1, Site A).

Diagnosis. Insertion of the branchial lobes exposed beyond collar. Radiolar tips long, lateral flanges very narrow. Dorsal lips triangular, erect, ventral lips rounded small. Anterior peristomial ring lobe exposed beyond collar, distally bilobed. Dorsal pockets not developed. Ventral collar shield horseshoe-shaped, not swollen. Paleate chaetae with short mucro. Acicular thoracic uncini with a large tooth followed by 3 smaller teeth surmounted the main fang. Anterior abdominal uncini with a large tooth above the main fang, followed by three rows of smaller teeth. Posterior uncini modified with the main fang surmounted by 6-7 rows of equal-size teeth. Pygidium with triangular posterior margin and short cirrus.

Taxonomic notes. $P$. gambiae is unique in having acidophil glands on the epidermis, as well as a glandular ridge on chaetiger 9 , and a laterally broad glandular ridge on chaetiger 2 .

Ecology and distribution. Our findings represent the second record of the species, and the first from Egyptian Mediterranean waters. The species was found at $50 \mathrm{~m}$ depth, on sandy bottoms. Previously known only from the Gulf of Naples (Tyrrhenian Sea) from sandy bottom at $7 \mathrm{~m}$ depth (Tovar-Hernández et al., 2007).

\section{Conclusions}

Among the 14 species included in Dialychone (Tovar-Hernández, 2008), only six (D. acustica Claparède, 1870, D. arenicola (Langerhans, 1880), D. collaris, D. dunerificta, D. longiseta (Giangrande, 1992), and D. usticensis were known to date from the Mediterranean Sea. The description of $D$. egyptica sp.n. increases this number up to seven. However, only four of them (including the new species) are known from the Egyptian Mediterranean waters. The data on most Dialychone species are fragmentary, and further studies will be required to precise their real distribution.
The genus Paradialychone includes 12 species, while only one (i.e. P. gambiae) is known from the Mediterranean (to date, only from the type locality). Our finding confirms its presence in Mediterranean waters, and increases its area of distribution from the Tyrrhenian Sea to the coast of Egypt.

\section{Acknowledgements}

We are very grateful to the staff of the Institute of Oceanography and Fisheries of Alexandria (Egypt) and the crew of R/V Salsabeel for their help in collecting of the material, and to Dr. Kirk Fitzhugh (Los Angeles County Museum of Natural History, Allan Hancock Foundation) for his help with literature. A special debt of gratitude is extended to Dr. Maria TovarHernández (Departamento de Ecología Acuática, El Colegio de la Frontera Sur, Unidad Chetumal, México) for her advises and fruitful discussion on the manuscript. We are also thankful to Dr. D. Martin (Blanes, Spain) for the revision of manuscript. The first author (SAS) greatly appreciates Mrs. T.S. Aksiuk and the staff of the Laboratory of Ecology and Morphology of Marine Invertebrates (A.N. Severtsov Institute of Ecology and Evolution RAS, Moscow, Russia) for their help during her visit to Moscow.

\section{References}

Abd-Elnaby F.A. 2005. Systematic and environmental studies on polychaetes from Alexandria marine waters. Ph.D Thesis. Suez Canal Univ. 330 p.

Banse K. 1972. Redescription of some species of Chone Krøyer and Euchone Malmgren, and three new species (Sabellidae, Polychaeta) // Fishery Bulletin. Fish and Wildlife Service. United States Department of Interior. Vol.70. No.2. P.459-495.

Cochrane S.J. 2003. Snowflakes and feather-duster-some challenges for soft-bottom fanworm systematics // Hydrobiologia. Vol.496. No.1-3. P.49-62.

Day J.H. 1967. A monograph on the Polychaeta of the Southern Africa. Part II. Sedentaria // British Museum (Natural History) Publication. No.656. P.459-878.

Fauchald K., Bellan G. 2012. Chone collaris. In: Read G., Fauchald, K. World Polychaeta database. Accessed through: World Register of Marine Species at http:// www.marinespecies.org/aphia.php? $\mathrm{p}=$ taxdetails\&id $=130887$ on $2012-07-30$. 
Fauvel P. 1937. Les fonds de pêche prês d'Alexandrie XI. Annélides Polychètes // Direction des recherches Pêcheries. Notes et Mémories. No.19. P.1-60.

Fauvel P. 1927. Polychètes sédentaires. Addenda aux errantes, archiannélides, myzostomaires // Faune de France. Vol.16. P.1-494.

Fauvel P. 1937. Les fonds de pêche prés d'Alexandrie XI. Annélides Polychètes // Direction des recherches Pêcheries. Notes et Mémories. No.19. P.1-60.

Fitzhugh K. 1989. A systematic revision of the SabellidaeCaobangiidae-Sabellongidae complex (Annelida: Polychaeta) // Bulletin of the American Museum of Natural History. No.192. P.1-104.

Giangrande A. 1992. The genus Chone (Polychaeta, Sabellidae) in the Mediterranean Sea with description on C. longiseta n. sp. // Bolletino di zoologia. Vol.59. No.4. P.517-529.

Giangrande A., Licciano M. 2006. The genus Euchone (Polychaeta, Sabellidae) in the Mediterranean Sea, addition of two new species and discussion on some closely related taxa // Journal of Natural History. Vol.40. No.21-22. P.1301-1330.

Giangrande A., Licciano M., Castriota L. 2006. Description of Chone usticensis sp.nov. (Polychaeta, Sabellidae) from the Mediterranean Sea//Zootaxa. No.1168. P.51-58.

Langerhans P. 1880. Die Wurmfauna von Madeira. III // Zeitschrift für wissenschaftliche Zoologie. Bd.34. No.1. S.87-143.

Malmgren A.J. 1867. Annulata Polychaeta Spetsbergiae, Groenlandiae, Islandiae et Scandinaviae hactenus cognita. Helsingfors. 127 p.

Nishi E., Tanaka K., Tovar-Hernández M.A., Giangrande A. 2009. Dialychone, Jasmineira and Paradialychone (Annelida: Polychaeta: Sabellidae) from Japan and adjacent waters, including four new species descriptions // Zootaxa. No.2167. P.1-66.

Potts F.A. 1928. Zoological results of the Cambridge expedition to the Suez Canal, 1924. Report on the Annelids (Sedentary Polychaetes) // Transactions of the Zoological Society of London. Vol.22. P.693705 .

Rouse G. W., Pleijel F. 2001. Polychaetes. New York: Oxford University Press. 354 p.

Selim S.A. 2008. New records of sabellid species (Polychaeta: Sabellidae) from the coastal Egyptian waters // Egyptian Journal of Aquatic Research. Vol.34. No.1. P.108-125.

Tovar-Hernández M.A. 2005. Redescription of Chone americana Day, 1973 (Polychaeta: Sabellidae) and description of five new species from the Grand Caribbean Region // Zootaxa. No.1070. P.1-30.

Tovar-Hernández M.A. 2007a. On some species of Chone Krøyer, 1856 (Polychaeta: Sabellidae) from worldwide localities // Zootaxa. No.1518. P.31-68.

Tovar-Hernández M. A. 2007b. Revision of Chone Krøyer, 1865 (Polychaeta: Sabellidae) from North America and descriptions of four new species // Journal of Natural History. Vol.41. No.9-12. P.511-566.

Tovar-Hernández M.A. 2008. Phylogeny of Chone Krøyer, 1856 (Polychaeta: Sabellidae) and related genera // Journal of Natural History. Vol.42. No.33-34. P.2193-2226.

Tovar-Hernández M.A., Dean H. 2010. Four new species of fan worms (Polychaeta: Sabellidae) from worldwide localities // Scientia Marina. Vol.74. No.4. P.815826.

Tovar-Hernández M.A., Sosa-Rodríguez T. 2006. Redescription of Chone infundibuliformis Krøyer, 1856 (Polychaeta: Sabellidae) and histology of the branchial crown appendages, collar and glandular ridge // Zootaxa. No.1115. P.31-59.

Tovar-Hernández M.A., Licciano M., Giangrande A. 2007. Revision of Chone Krøyer, 1856 (Polychaeta: Sabellidae) from the eastern central Atlantic and Mediterranean Sea with descriptions of two new species // Scientia Marina. Vol.7. No.2. P.315-338.

Responsible editor E.N. Temereva 